\title{
Effect of Three Harvest Intervals on Yield and Composition of Nineteen Forage Grasses in the Humid Mountain Region of Puerto Rico ${ }^{1,2}$
}

\author{
A. Sotomayor-Ríos, J. Vélez-Santiago, S. Torres-Rivera, and S. Silva ${ }^{3}$
}

\section{ABSTRACT}

The response of 19 forage grasses to three cutting intervals in the humid mountain region of Puerto Rico was evaluated. Nine Brachiarias, nine Digitarias, and one Cynodon species were evaluated during a 2-year period under cutting management at the Corozal Substation for green forage (GF), dry forage (DF), and crude protein (CP) yields and for dry matter (DM), crude protein (CP), $\mathrm{Ca}, \mathrm{P}, \mathrm{K}$, and $\mathrm{Mg}$ contents.

In terms of green forage yield (GFY), the most productive species at the 30-day harvest interval was D. setivalva (PRPI 6402) with $86,794 \mathrm{~kg} /$ ha/year. At the 45- and 60-day harvest intervals, Brachiaria sp. (PRPI 9626) produced 102,116 and 109,213 kg/ha/year, respectively. This species also produced the highest DFY at the 30-day harvest interval with $18,430 \mathrm{~kg} / \mathrm{ha} /$ year. C. nlemfuensis, var. nlemfuensis (PRPI 2341), stargrass, and B. decumbens (PRPI 5365) produced the highest DFY at the 45- and 60-day intervals with 21,758 and $27,238 \mathrm{~kg} / \mathrm{ha} /$ year, respectively.

The highest CP content at the 30-, 45-, and 60-day intervals was observed on the three Digitaria hybrids, D. pentzii $\times$ D. smutzii (PRPI 9621), D. pentzii $\times D$. milanjiana (PRPI 9619), and D. pentzii $\times D$. pentzii (PRPI 9620) with 14.3, 12.0, and $11.1 \%$, respectively.

D. decumbens (PRPI 6439), 'Transvala' Digitgrass, produced the highest CP yield at the 30-day harvest interval with $2,179 \mathrm{~kg} / \mathrm{ha} /$ year. Stargrass had the highest CP yield at the 45- and 60-day harvest intervals with 2,141 and $2,030 \mathrm{~kg} / \mathrm{ha} /$ year, respectively.

The $\mathrm{P}, \mathrm{Ca}, \mathrm{Mg}$, and $\mathrm{K}$ contents of the 19 grasses on the average decreased as the harvest interval increased. A sharp decrease (from 1.81 to 1.47 to $1.42 \%$ ) of the $\mathrm{K}$ content of the grasses was observed at the 30 -, $45-$, and 60-day intervals, respectively.

${ }^{1}$ Manuscript submitted to the Editorial Board August 22, 1973.

${ }^{2}$ This paper covers work carried out cooperatively between the Agricultural Experiment Station, College of Agricultural Sciences, Mayagüez Campus, University of Puerto Rico, Rio Piedras, and the Soil and Water Conservation Research Division, Agricultural Research Service, USDA, Río Piedras, P.R.

${ }^{3}$ Research Geneticist, ARS, USDA, Mayagüez, P.R. (formerly Plant Breeder and Administrator, Corozal Substation, Agricultural Experiment Station, College of Agricultural Sciences, Mayagüez Campus, University of Puerto Rico, Río Piedras, P.R.); Assistant Agronomist, and Agricultural Technician, SWCRD, ARS, USDA, Río Piedras, P.R. 
The GFY, DFY, and DM of the 19 grasses increased on the average with the length of the harvest interval. On the other hand, the CP content and yield of the 19 grasses decreased as the harvest interval increased.

No significant correlation was obtained between total rainfall, CP, and DFY of the 19 grasses. Significant positive correlations were obtained between DFY of the 19 grasses and average temperature. A significant negative correlation was obtained between average temperature and $\mathrm{CP}$ content.

\section{INTRODUCTION}

Studies of response of major tropical grasses to harvest intervals, cutting heights, and the effect of these treatments on the chemical composition of the forage have been conducted in Puerto Rico. Vicente Chandler et al. $(15,18)$ and Caro-Costas et al. $(2,4)$ reported that the annual green forage yield (GFY) and dry forage yield (DFY) of pangola (Digitaria decumbens Stent.), guinea (Panicum maximum), star (Cynodon nlemfuensis var. nlemfuensis), congo (Brachiaria ruziziensis), merker (Pennisetum purpureum), para (Brachiaria mutica), and other grasses increase with length of harvest interval, while percentage content of crude protein (CP), $\mathrm{P}$, and $\mathrm{K}$ decrease.

A large number of grass species belonging to various genera have been studied in Puerto Rico under cutting management (11, 12, 13, 14, 18). Annual DFY of 36,370 and $44,504 \mathrm{~kg} / \mathrm{ha}$ have been reported by Sotomayor-Ríos et al. $(11,14)$ on Digitaria eriantha and glabrous signalgrass, Brachiaria brizantha, when these grasses were cut every 60 days. At Isabela, Puerto Rico, Digitaria decumbens (P.I. 299752) produced annual DFY of 28,988 and $33,105 \mathrm{~kg} / \mathrm{ha}$ at 30 - and 45 -day intervals, respectively (12). In the same study, stargrass produced annual DFY of $42,642 \mathrm{~kg} / \mathrm{ha}$ at the 60 -day interval.

Based partially on these results, the supposedly highest yielding: species, together with various introductions not previously tested, were selected for a study designed to compare the yield and composition of 19 promising grasses in the humid mountain region of Puerto Rico as affected by three cutting intervals.

\section{MATERIALS AND METHODS}

Excellent examples of utilization of grasses in the Digitaria $(1,6,7,8$, $10,17)$ Brachiaria $(9,17)$, and Cynodon $(2,5,17)$ genera have been cited in the literature. Grass species in these genera are important components of natural and improved pastures in many parts of the world. The diversity and large number of species in these three genera merit as detailed an evaluation as forage crops as possible for their final 
utilization in the diverse and climatic conditions prevailing in the Tropics.

In this study the 19 grasses (table 1) were established on a deep, red, acid, moderately well-drained Corozal clay (Ultisol) on a 15 to $20 \%$ slope at the Corozal Substation, located at an elevation of about $214 \mathrm{~m}$ in the humid mountain region of Puerto Rico.

TABle 1.-Identification of 19 forage grasses evaluated at Corozal, Puerto Rico

\begin{tabular}{|c|c|c|c|}
\hline \multirow{2}{*}{ Species } & \multicolumn{3}{|c|}{ Plant Introduction Number } \\
\hline & USDA PI $^{1}$ & $\mathrm{PRPI}^{2}$ & Common name \\
\hline Brachiaria brizantha (Hochst) Stapf. & - & 1525 & Signal \\
\hline Brachiaria brizantha (Hochst) Stapf. & - & 5567 & - \\
\hline $\begin{array}{l}\text { Brachiaria ruziziensis (Germain et } \\
\text { Everard) }\end{array}$ & 247404 & 5366 & Congo \\
\hline Brachiaria mutica (Forsk) Stapf. & 299499 & 6451 & Tanner \\
\hline Brachiaria brizantha Stapf. & 255346 & 5909 & $\begin{array}{l}\text { Signal } \\
\text { (glabrous) }\end{array}$ \\
\hline Brachiaria brizantha Stapf. & - & 5569 & - \\
\hline Digıtaria pentzii $\times D$ D. smutsii & - & 9621 & U.F. $38^{3}$ \\
\hline Brachiaria decumbens Stapf. & 210724 & 5365 & - \\
\hline Digitaria setivalva Stent. & 299892 & 6402 & - \\
\hline Digitaria pentzii $\times D$. milanjiana & - & 9619 & U. F. 59-1 \\
\hline Digitaria decumbèns Stent. & - & 5124 & A-24 \\
\hline Brachiaria sp. & 299497 & 9626 & - \\
\hline Cynodon nlemfuensis var. nlemfuensis & - & 2341 & Star \\
\hline Digitaria milanjiana subsp. eylesiana & 299731 & 6416 & - \\
\hline Digitaria decumbens Stent. & 299752 & 6439 & $\begin{array}{l}\text { 'Transvala' } \\
\text { Digitgrass }\end{array}$ \\
\hline Digitaria smutsii Stent. & 299828 & 6434 & - \\
\hline Digitaria pentzii $\times D$. pentzii & - & 9620 & U. F. $42-1$ \\
\hline Digitaria decumbens Stent. & 111110 & 0560 & $\begin{array}{l}\text { 'Pangola' } \\
\text { Digitgrass }\end{array}$ \\
\hline Brachiaria decumbens Stapf. & - & 9625 & - \\
\hline
\end{tabular}

${ }^{1}$ United States Department of Agriculture plant introduction number.

${ }^{2}$ University of Puerto Rico Agricultural Experiment Station plant introduction number.

${ }^{3}$ University of Florida.

The grasses were evaluated over two consecutive years using a randomized split-plot design and three harvest intervals, 30, 45, and 60 days, as the subplots. A 15-5-10 fertilizer was applied at a rate of 2,400 $\mathrm{kg} /$ ha yearly in 6,8 , and 12 equal applications corresponding to the harvest intervals tested. At the start of the experiment all plots were limed to about $\mathrm{pH} 5.5$.

Main plots were $8.10 \times 4.50 \mathrm{~m}$ and subplots $2.70 \times 4.50 \mathrm{~m}$. A center swath $1.05 \times 4.50 \mathrm{~m}$ was cut and the forage weighed, sampled, and removed at the prescribed interval. 
DM and CP contents were determined in all samples. For each harvest interval, samples were composited by replications and by individual cuttings and analyzed for $\mathrm{P}, \mathrm{K}, \mathrm{Ca}$, and $\mathrm{Mg}$.

\section{RESULTS AND DISCUSSION}

\section{FORAGE YIELD}

The data in tables 2, 3, 4, and figures 1, 2, 3, show the yields of the 19 grasses at the 30-, 45-, and 60-day intervals. The highest GFY at the 30-day interval was obtained by Digitaria setivalva (PRPI 6402) with $86,794 \mathrm{~kg} / \mathrm{ha} /$ year. Digitaria pentzii $\times$ D. milanjiana (PRPI 9619), had the lowest GFY with $49,518 \mathrm{~kg} / \mathrm{ha} /$ year. At the 45 -day interval Brachiaria sp., (PRPI 9626) had the highest GFY with $102,116 \mathrm{~kg} / \mathrm{ha} /$ year. The lowest GFY at the 45-day interval was obtained with Digitaria pentzii $\times$ D. pentzii (PRPI 9620), with 56,523 kg/ha/year. At the 60 -day interval Brachiaria sp. (PRPI 9626) had the highest GFY with 109,213 kg/ha/ year. The lowest GFY at the 60-day interval was observed on D. pentzii $\times D$. pentzii with $54,537 \mathrm{~kg} / \mathrm{ha} /$ year.

Average GFY of the 19 grasses at the $30-, 45-$, and 60-day intervals were $67,861,78,487$, and $86,607 \mathrm{~kg} / \mathrm{ha} /$ year, respectively (table 5 ). The average yields of the 19 grasses at the 60-day interval were significantly better $(\mathrm{P}<.05)$ than those obtained at the 45 - and 30-day intervals. The average GFY of the 19 grasses at the 45-day interval were significantly better $(\mathrm{P}<.05)$ than those at the 30 -day interval.

At the 30-day interval, Brachiaria sp., (PRPI 9626) had the highest DFY with $18,430 \mathrm{~kg} /$ ha/year, while $D$. pentzii $\times D$. milanjiana (PRPI 9619), had the lowest DFY. Stargrass (PRPI 2341) exhibited the highest DFY at the 45 -day interval with $21,758 \mathrm{~kg} / \mathrm{ha} /$ year. The lowest DFY at the 45-day interval was observed on $D$. pentzii $\times D$. pentzii (PRPI 9620) with $13,649 \mathrm{~kg} / \mathrm{ha} /$ year. Brachiaria decumbens (PRPI 5365) had the highest DFY at the 60-day interval with $27,238 \mathrm{~kg} / \mathrm{ha} /$ year, while PRPI 9620 had the lowest with 13,718 .

The average DFY of the 19 grasses increased with length of harvest interval. When cut at 30-, 45-, and 60-day intervals, the average DFY of the 19 grasses were $14,987,18,786$, and $22,057 \mathrm{~kg} / \mathrm{ha} /$ year, respectively (table 5). The average yields at the 60-day interval were significantly better $(\mathrm{P}<.05$ ) than at 45 - and 30-day harvest intervals, respectively. The average DFY at the 45-day interval were also significantly better ( $\mathrm{P}$ $<.05)$ than those at the 30 -day interval.

In general, the DFY of most of the grasses in this experiment were somewhat low. Vicente-Chandler et al. (17) reported DFY of over 33,000 $\mathrm{kg} / \mathrm{ha} /$ year for congograss (PRPI 5366) when this grass was cut every 60 days at Corozal during a 2-year period. At Corozal, also, Sotomayor-Ríos 
TABLE 2.-Yield and crude protein content of 19 forage grasses cut every 30 days over a 2-year period at Corozal

\begin{tabular}{|c|c|c|c|c|c|c|}
\hline Species & $\begin{array}{l}\text { PRPI } \\
\text { Number }\end{array}$ & $\begin{array}{c}\text { Weighted } \\
\text { green } \\
\text { forage } \\
\text { yields }\end{array}$ & $\begin{array}{c}\text { Dry } \\
\text { matter } \\
\text { content }\end{array}$ & $\begin{array}{c}\text { Weighted } \\
\text { dry } \\
\text { forage } \\
\text { yields }\end{array}$ & $\begin{array}{l}\text { Crude } \\
\text { protein } \\
\text { content }\end{array}$ & $\begin{array}{l}\text { Weighted } \\
\text { crude } \\
\text { protein } \\
\text { yields }\end{array}$ \\
\hline & & $\mathrm{Kg} / \mathrm{ha} /$ year & $\%$ & $\mathrm{Kg} / \mathrm{ha} /$ year & $\%$ & Kg/ha/year \\
\hline Digitaria setivalva & 6402 & $86,794 \mathrm{a}^{1}$ & $20.2 \mathrm{~g}$ & $16,070 \mathrm{ad}$ & $13.3 \mathrm{bc}$ & 1,946 ad \\
\hline Brachiaria sp. & 9626 & $84,576 \mathrm{ab}$ & $23.2 \mathrm{de}$ & $18,430 \mathrm{a}$ & $11.1 \mathrm{e}$ & $1,870 \mathrm{ad}$ \\
\hline Brachiaria mutica & 6451 & 82,183 ac & $20.8 \mathrm{fg}$ & $15,982 \mathrm{ad}$ & $13.8 \mathrm{ab}$ & $2,051 \mathrm{ab}$ \\
\hline Digitaria decumbens & 6439 & $75,841 \mathrm{ad}$ & $24.8 \mathrm{bd}$ & $16,947 \mathrm{ac}$ & $13.8 \mathrm{ab}$ & $2,179 \mathrm{a}$ \\
\hline Brachiaria decumbens & 5365 & $75,609 \mathrm{ad}$ & 24.4 bd & $17,114 \mathrm{ab}$ & 11.6 de & $1,866 \mathrm{ad}$ \\
\hline Brachiaria brizantha & 5909 & 75,376 ad & $24.6 \mathrm{bd}$ & $17,138 \mathrm{ab}$ & $12.0 \mathrm{~d}$ & $1,958 \mathrm{ac}$ \\
\hline Digitaria pentzii $\times$ D. smutsii & 9621 & 74,889 ad & 22.4 ef & 14,747 be & $14.3 \mathrm{a}$ & 1,929 ad \\
\hline Digitaria milanjiana & 6416 & 71,972 be & $24.2 \mathrm{bd}$ & $15,113 \mathrm{bd}$ & $13.8 \mathrm{ab}$ & $1,938 \mathrm{ad}$ \\
\hline Brachiaria brizantha & 5569 & $70,277 \mathrm{cf}$ & $24.8 \mathrm{bd}$ & $15,854 \mathrm{ad}$ & $14.0 \mathrm{ab}$ & $2,062 \mathrm{ab}$ \\
\hline Brachiaria decumbens & 9625 & $66,943 \mathrm{df}$ & $24.6 \mathrm{bd}$ & $15,400 \mathrm{bd}$ & $13.3 \mathrm{bc}$ & $1,910 \mathrm{ad}$ \\
\hline Digitaria smutsii & 6434 & $66,362 \mathrm{df}$ & $24.1 \mathrm{ce}$ & 14,590 be & $13.8 \mathrm{ab}$ & 1,830 be \\
\hline Brachiaria ruziziensis & 5366 & $62,029 \mathrm{eg}$ & $24.8 \mathrm{bd}$ & $13,684 \mathrm{df}$ & $11.2 \mathrm{de}$ & $1,437 \mathrm{f}$ \\
\hline Digitaria decumbens & 5124 & $61,436 \mathrm{eg}$ & $25.1 \mathrm{bc}$ & $13,748 \mathrm{df}$ & $13.8 \mathrm{ab}$ & $1,757 \mathrm{bf}$ \\
\hline Digitaria decumbens & 0560 & $60,601 \mathrm{eg}$ & $25.6 \mathrm{bc}$ & $13,790 \mathrm{df}$ & $13.3 \mathrm{bc}$ & $1,711 \mathrm{cf}$ \\
\hline Brachiaria brizantha & 5567 & $60,125 \mathrm{eg}$ & $25.8 \mathrm{bc}$ & 14,448 be & $12.8 \mathrm{c}$ & $1,758 \mathrm{bf}$ \\
\hline Brachiaria brizantha & 1525 & $58,940 \mathrm{fg}$ & $25.6 \mathrm{bc}$ & $14,076 \mathrm{ce}$ & $12.0 \mathrm{~d}$ & $1,618 \mathrm{df}$ \\
\hline Cynodon nlemfuensis var. nlemfuensis & 2341 & $52,783 \mathrm{~g}$ & $29.5 \mathrm{a}$ & 14,450 be & $14.0 \mathrm{ab}$ & $1,883 \mathrm{ad}$ \\
\hline Digitaria pentzii $\times$ D. pentzii & 9620 & $52,435 \mathrm{~g}$ & $25.5 \mathrm{bc}$ & 12,053 ef & $13.8 \mathrm{ab}$ & $1,525 \mathrm{ef}$ \\
\hline Digitaria pentzii $\times D$. milanjiana & 9619 & $49,518 \mathrm{~g}$ & $26.1 \mathrm{~b}$ & $11,118 \mathrm{f}$ & $14.0 \mathrm{ab}$ & $1,440 \mathrm{f}$ \\
\hline
\end{tabular}

${ }^{1}$ Means followed by the same letter are not significantly different at the 0.05 level of probability. 
TABLE 3.-Yield and crude protein content of 19 forage grasses cut every 45 days over a 2-year period at Corozal

\begin{tabular}{|c|c|c|c|c|c|c|}
\hline Species & $\begin{array}{l}\text { PRPI } \\
\text { Number }\end{array}$ & $\begin{array}{l}\text { Weighted } \\
\text { green } \\
\text { forage } \\
\text { yields }\end{array}$ & $\begin{array}{c}\text { Dry } \\
\text { matter } \\
\text { content }\end{array}$ & $\begin{array}{l}\text { Weighted } \\
\text { dry } \\
\text { forage } \\
\text { yields }\end{array}$ & $\begin{array}{l}\text { Crude } \\
\text { protein } \\
\text { content }\end{array}$ & $\begin{array}{l}\text { Weighted } \\
\text { crude } \\
\text { protein } \\
\text { yields }\end{array}$ \\
\hline & & Kg/ha/year & $\%$ & $\mathrm{Kg} / \mathrm{ha} /$ year & $\%$ & $\mathrm{Kg} / \mathrm{ha} /$ year \\
\hline Brachiaria sp. & 9626 & $102,116 \mathrm{a}^{1}$ & $22.6 \mathrm{ef}$ & $21,703 \mathrm{a}$ & $9.0 \mathrm{i}$ & $1,824 \mathrm{ad}$ \\
\hline Digitaria setivalva & 6402 & $101,443 \mathrm{a}$ & $21.1 \mathrm{f}$ & 20,344 ac & $11.1 \mathrm{bd}$ & $2,066 \mathrm{ab}$ \\
\hline Brachiaria brizantha & 5909 & $91,186 \mathrm{ab}$ & $24.7 \mathrm{~cd}$ & $21,486 \mathrm{ab}$ & $9.3 \mathrm{hi}$ & $1,907 \mathrm{ac}$ \\
\hline Brachiaria mutica & 6451 & $87,724 \mathrm{bc}$ & $22.8 \mathrm{ef}$ & $19,508 \mathrm{ad}$ & $10.3 \mathrm{dg}$ & $1,902 \mathrm{ac}$ \\
\hline Brachiaria decumbens & 5365 & $87,549 \mathrm{bc}$ & $25.5 \mathrm{bd}$ & $21,393 \mathrm{ab}$ & $9.5 \mathrm{gi}$ & $1,961 \mathrm{ac}$ \\
\hline Digitaria milanjiana & 6416 & $87,213 \mathrm{bc}$ & $24.6 \mathrm{~cd}$ & 20,116 ad & $10.8 \mathrm{be}$ & $2,009 \mathrm{ab}$ \\
\hline Digitaria pentzii $\times D$ D. smutsii & 9621 & $84,262 \mathrm{bd}$ & $22.3 \mathrm{ef}$ & $17,478 \mathrm{cg}$ & $11.5 \mathrm{ab}$ & $1,836 \mathrm{ac}$ \\
\hline Brachiaria brizantha & 5569 & 82,380 be & $25.8 \mathrm{bd}$ & $19,760 \mathrm{ad}$ & $11.4 \mathrm{ab}$ & $2,018 \mathrm{ab}$ \\
\hline Digitaria smutsii & 6434 & 81,695 bf & $25.6 \mathrm{bd}$ & $19,695 \mathrm{ad}$ & $11.2 \mathrm{ac}$ & $1,864 \mathrm{ac}$ \\
\hline Brachiaria decumbens & 9625 & $78,466 \mathrm{bf}$ & $24.6 \mathrm{~cd}$ & 18,636 be & $10.1 \mathrm{eh}$ & $1,800 \mathrm{bd}$ \\
\hline Digitaria decumbens & 6439 & $74,911 \mathrm{cf}$ & $27.2 \mathrm{~b}$ & $19,383 \mathrm{ad}$ & $10.3 \mathrm{dg}$ & $1,834 \mathrm{ac}$ \\
\hline Brachiaria riziziensis & 5366 & $72,344 \mathrm{dg}$ & 24.0 de & $16,247 \mathrm{eh}$ & $9.7 \mathrm{fi}$ & $1,460 \mathrm{e}$ \\
\hline Digitaria decumbens & 5124 & $70,787 \mathrm{eg}$ & $26.1 \mathrm{bc}$ & $17,288 \mathrm{dg}$ & $11.6 \mathrm{ab}$ & $1,811 \mathrm{ad}$ \\
\hline Brachiaria brizantha & 5567 & $70,207 \mathrm{eg}$ & $26.7 \mathrm{~b}$ & $18,368 \mathrm{cf}$ & $10.4 \mathrm{df}$ & 1,754 be \\
\hline Digitaria decumbens & 0560 & $69,440 \mathrm{fg}$ & $26.5 \mathrm{bc}$ & $17,286 \mathrm{dg}$ & $10.5 \mathrm{cf}$ & 1,662 ce \\
\hline Cynodon nlemfuensis var. nlemfuensis & 2341 & $69,092 \mathrm{fg}$ & $32.5 \mathrm{a}$ & $21,758 \mathrm{a}$ & $10.3 \mathrm{dg}$ & 2,141 a \\
\hline Brachiaria brizantha & 1525 & $62,087 \mathrm{gh}$ & $26.4 \mathrm{bc}$ & $15,787 \mathrm{fh}$ & $9.8 \mathrm{fi}$ & 1,504 de \\
\hline Digitaria pentzii $\times$ D. milanjiana & 9619 & $61,821 \mathrm{gh}$ & $26.4 \mathrm{bc}$ & $15,016 \mathrm{gh}$ & $12.0 \mathrm{a}$ & 1,642 ce \\
\hline Digitaria pentzii $\times D$. pentzii & 9620 & $56,523 \mathrm{~h}$ & $26.0 \mathrm{bc}$ & $13,649 \mathrm{~h}$ & $11.3 \mathrm{ab}$ & $1,482 \mathrm{e}$ \\
\hline
\end{tabular}

${ }^{1}$ Means followed by the same letter are not significantly different at the 0.05 level of probability. 
TABLE 4.-Yield and crude protein content of 19 forage grasses cut every 60 days over a 2-year period at Corozal

\begin{tabular}{|c|c|c|c|c|c|c|}
\hline Species & $\begin{array}{l}\text { PRPI } \\
\text { Number }\end{array}$ & $\begin{array}{l}\text { Weighted } \\
\text { green } \\
\text { forage } \\
\text { yields }\end{array}$ & $\begin{array}{c}\text { Dry } \\
\text { matter } \\
\text { content }\end{array}$ & $\begin{array}{l}\text { Weighted } \\
\text { dry } \\
\text { forage } \\
\text { yields }\end{array}$ & $\begin{array}{l}\text { Crude } \\
\text { protein } \\
\text { content }\end{array}$ & $\begin{array}{l}\text { Weighted } \\
\text { crude } \\
\text { protein } \\
\text { yields }\end{array}$ \\
\hline & & Kg/ha/year & $\%$ & $\mathrm{Kg} / \mathrm{ha} /$ year & $\%$ & Kg/halyear \\
\hline Brachiaria sp. & 9626 & $109,213 \mathrm{a}^{1}$ & $23.4 \mathrm{~h}$ & $25,395 \mathrm{ac}$ & 8.3 ef & $1,617 \mathrm{ch}$ \\
\hline Brachiaria decumbens & 5365 & $105,775 \mathrm{ab}$ & $26.5 \mathrm{de}$ & $27,238 \mathrm{a}$ & $7.9 \mathrm{f}$ & $1,887 \mathrm{ad}$ \\
\hline Digitaria setivalua & 6402 & $104,521 \mathrm{ac}$ & $22.8 \mathrm{~h}$ & $22,886 \mathrm{ce}$ & $9.3 \mathrm{~cd}$ & 1,790 af \\
\hline Brachiaria brizantha & 5909 & $100,966 \mathrm{ad}$ & $26.4 \mathrm{de}$ & $26,105 \mathrm{ab}$ & $7.8 \mathrm{f}$ & $1,696 \mathrm{bh}$ \\
\hline Brachiaria mutica & 6451 & 97,214 ae & $25.4 \mathrm{eg}$ & $24,227 \mathrm{bd}$ & $9.3 \mathrm{~cd}$ & $2,010 \mathrm{ab}$ \\
\hline Brachiaria brizantha & 5567 & 96,203 be & $28.4 \mathrm{bc}$ & $27,022 \mathrm{a}$ & $7.7 \mathrm{f}$ & 1,827 ae \\
\hline Digitaria milanjiana & 6416 & 96,076 be & $25.8 \mathrm{dg}$ & 23,827 be & $9.5 \mathrm{bd}$ & 1,925 ac \\
\hline Digitaria pentzii $\times$ D. smutsii & 9621 & $92,231 \mathrm{cf}$ & $24.5 \mathrm{fh}$ & $21,287 \mathrm{eg}$ & $9.7 \mathrm{bd}$ & $1,764 \mathrm{ag}$ \\
\hline Brachiaria decumbens & 9625 & $90,825 \mathrm{df}$ & $26.1 \mathrm{df}$ & $23,014 \mathrm{ce}$ & $8.5 \mathrm{ef}$ & $1,718 \mathrm{ah}$ \\
\hline Brachiaria brizantha & 5569 & $85,529 \mathrm{eg}$ & $27.1 \mathrm{ce}$ & $22,270 \mathrm{df}$ & $9.7 \mathrm{bd}$ & $1,711 \mathrm{ah}$ \\
\hline Brachiaria ruziziensis & 5366 & $83,670 \mathrm{fh}$ & $24.2 \mathrm{gh}$ & $19,570 \mathrm{fh}$ & 8.9 de & 1,483 fh \\
\hline Digitaria smutsii & 6434 & $81,718 \mathrm{fh}$ & $27.4 \mathrm{bd}$ & $22,154 \mathrm{df}$ & $9.7 \mathrm{bd}$ & $1,721 \mathrm{ah}$ \\
\hline Digitaria decumbens & 6439 & $80,441 \mathrm{fh}$ & $29.0 \mathrm{~b}$ & $22,344 \mathrm{df}$ & $9.5 \mathrm{bd}$ & 1,859 ae \\
\hline Cynodon nlemfuensis var. nlemfuensis & 2341 & 77,595 gi & $33.1 \mathrm{a}$ & $24,619 \mathrm{ad}$ & 9.2 de & $2,030 \mathrm{a}$ \\
\hline Digitaria decumbens (Pangola) & 0560 & $75,272 \mathrm{gi}$ & $27.0 \mathrm{ce}$ & $19,616 \mathrm{fh}$ & $9.6 \mathrm{~b}$ & $1,546 \mathrm{eh}$ \\
\hline Digitaria decumbens & 5124 & $74,796 \mathrm{gi}$ & 26.4 de & 19,025 gi & $10.1 \mathrm{bc}$ & $1,567 \mathrm{dh}$ \\
\hline Brachiaria brizantha & 1525 & 72,089 hi & $25.7 \mathrm{dg}$ & $18,216 \mathrm{hi}$ & $8.8 \mathrm{de}$ & $1,401 \mathrm{hi}$ \\
\hline Digitaria pentzii $\times$ D. milanjiana & 9619 & $66,873 \mathrm{i}$ & 27.2 be & $16,554 \mathrm{i}$ & $10.3 \mathrm{~b}$ & $1,437 \mathrm{gi}$ \\
\hline Digitaria pentzii $\times D$. pentzii & 9620 & $54,537 \mathrm{j}$ & 26.5 de & $13,718 \mathrm{j}$ & $11.1 \mathrm{a}$ & $1,158 \mathrm{i}$ \\
\hline
\end{tabular}

${ }^{1}$ Means followed by the same letter are not significantly different at the 0.05 level of probability. 
et al. (13) reported DFY of approximately $26,000 \mathrm{~kg} / \mathrm{ha} /$ year for tanner (PRPI 6451) and pangola when these grasses were cut every 60 days during a 2-year period. DFY of over $30,000 \mathrm{~kg} / \mathrm{ha} /$ year at Gurabo were reported by Sotomayor-Ríos et al. (11) for pangola, signal (PRPI 5909), star (PRPI 2341) and congo (PRPI 5366) when these grasses were cut

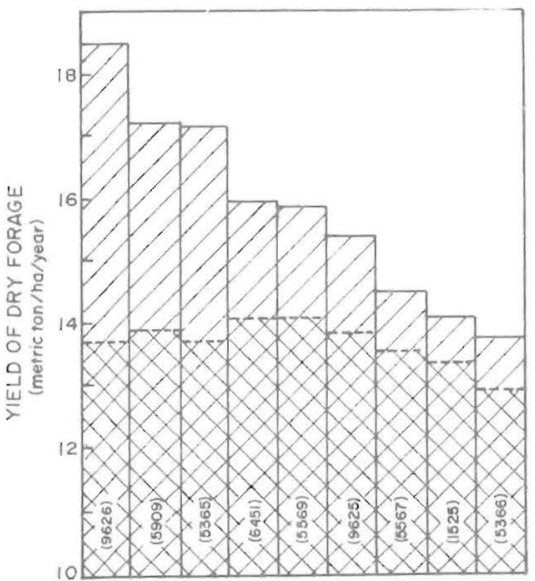

BRACHIARIAS

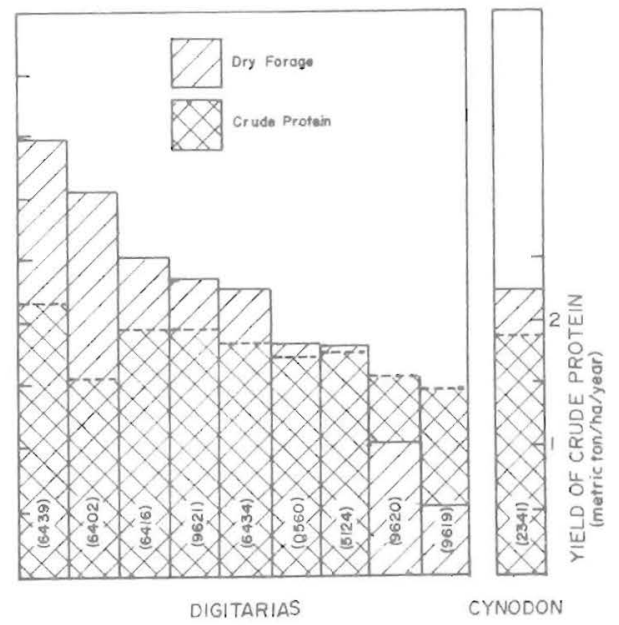

Fig. 1.-Dry forage and crude protein yields of 19 grasses cut every 30 days over a 2-year period at Corozal, P.R.
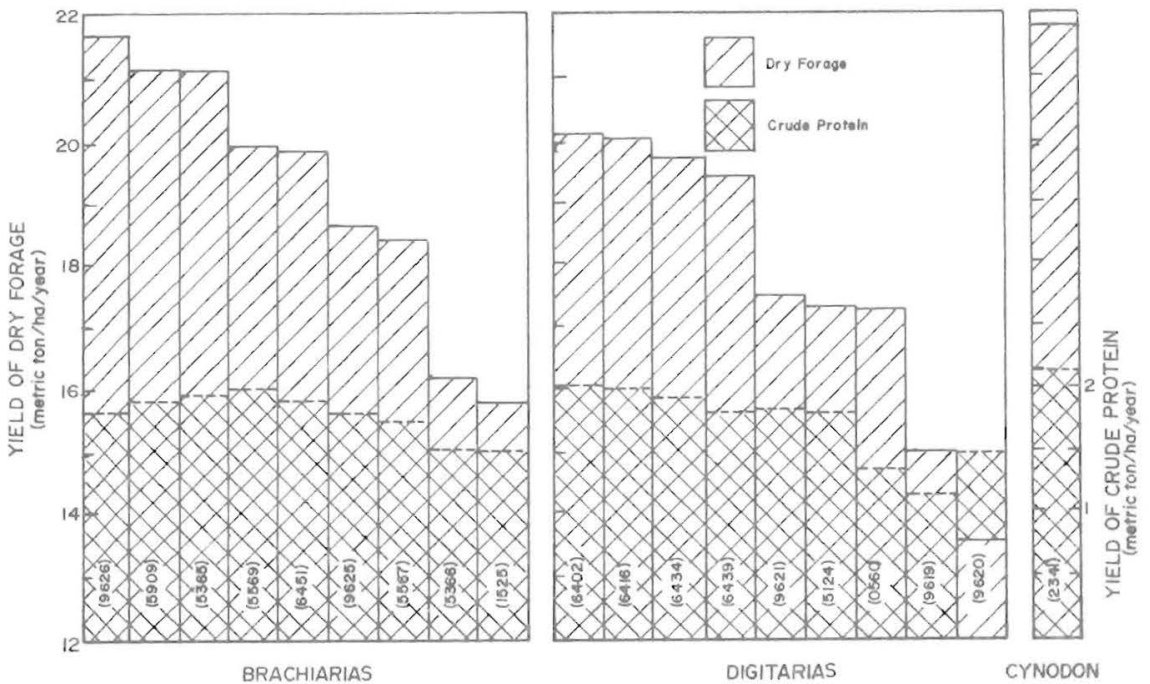

FIG. 2.-Dry forage and crude protein yields of 19 grasses cut every 45 days over a 2-year period at Corozal, P.R. 
every 60 days during a 2 -year period. In all cases approximately 672 $\mathrm{kg} / \mathrm{ha} /$ year of $\mathrm{N}$ were applied.

\section{PROTEIN CONTENT AND YIELDS}

The CP content and yield of the 19 grasses at the 30-, 45-, and 60-day intervals are shown in tables 2, 3,4 and figures 1, 2, 3. At the 30-day

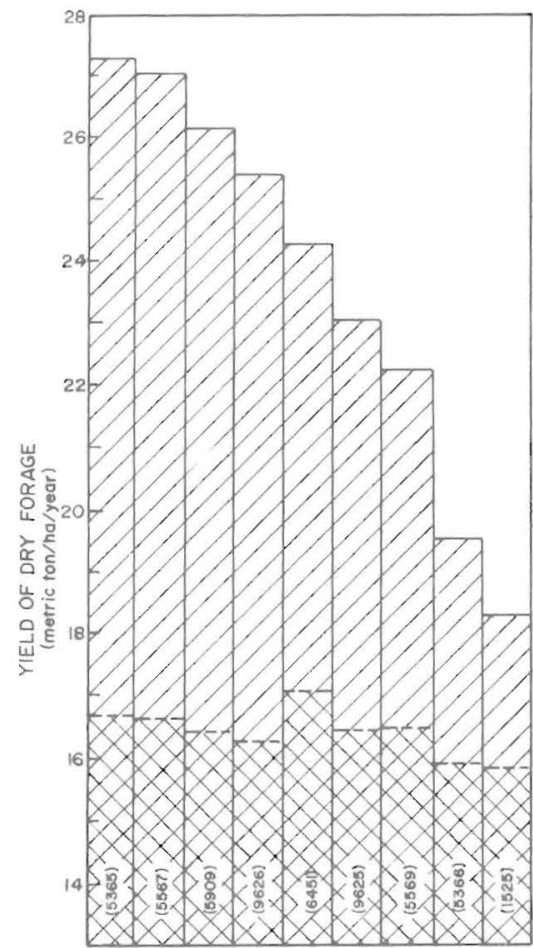

BRACHIARIAS

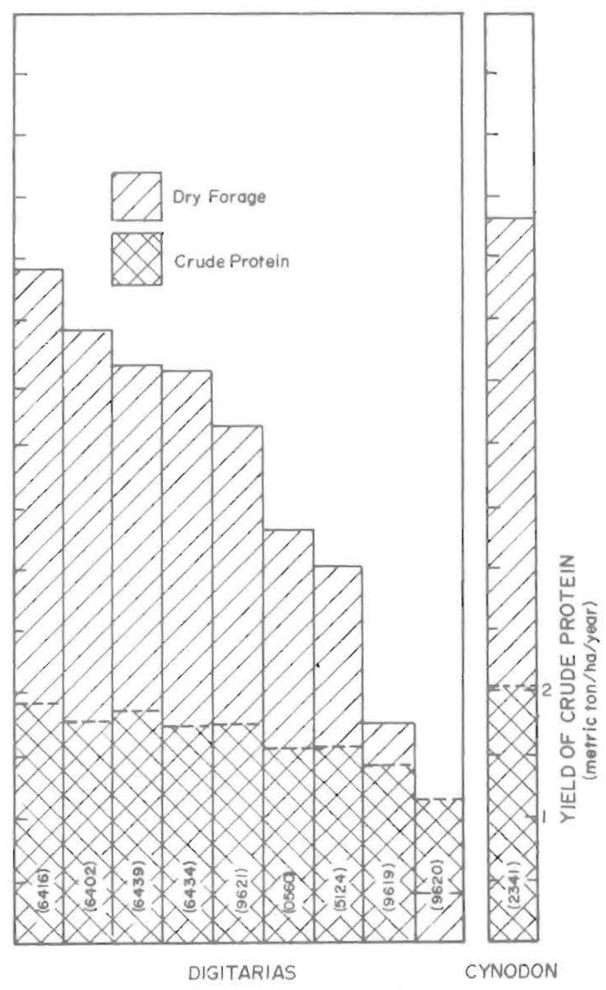

DIGITARIAS
CYNODON

FIG. 3.-Dry forage and crude protein yields of 19 grasses cut every 60 days over a 2 -year period at Corozal, P.R.

interval, D. pentzii $\times$ D. smutsii (PRPI 9621) had the highest CP with $14.3 \%$. The lowest $\mathrm{CP}$ at the 30-day interval was obtained from Brachiaria sp., (PRPI 9626) with $11.1 \%$. D. pentzii $\times$ D. milanjiana (PRPI 9619) had the highest CP at the 45-day interval with $12.0 \%$. The lowest CP at the 45-day interval was observed on Brachiaria sp. (PRPI 9626) with $9.0 \%$. At the 60 -day interval $D$. pentzii $\times D$. pentzii (PRPI 9620) had the highest CP with $11.1 \%$, being significantly higher than that of remaining 18 grasses. Brachiaria brizantha (PRPI 5567) had the lowest $\mathrm{CP}$ at the 60-day interval with $7.7 \%$. 
CP content, on the average, decreased as the harvest interval increased. The average $\mathrm{CP}$ at the $30-, 45-$, and 60-day intervals of the 19 grasses was $13.2,10.5$, and $9.2 \%$, respectively (table 5 ). The average CP at the 30-day interval was significantly higher than at the 45- and 60-day intervals, respectively. In turn, the average $\mathrm{CP}$ at the 45 -day interval, was significantly higher than at the 60-day interval.

TABLE 5.-Average yields, crude protein, and dry matter content of 19 forage grasses at three harvest intervals during a 2-year period at Corozal ${ }^{1}$

\begin{tabular}{cccccc}
\hline $\begin{array}{c}\text { Cutting } \\
\text { interval }\end{array}$ & $\begin{array}{c}\text { Green } \\
\text { forage }\end{array}$ & $\begin{array}{c}\text { Yields of } \\
\text { dry } \\
\text { forage }\end{array}$ & $\begin{array}{c}\text { Dry } \\
\text { matter } \\
\text { content }\end{array}$ & $\begin{array}{c}\text { Crude } \\
\text { protein }\end{array}$ & $\begin{array}{c}\text { Crude } \\
\text { protein }\end{array}$ \\
\hline & Kg/ha/year & Kg/ha/year & $\%$ & $\%$ & $\mathrm{Kg} /$ ha/year \\
60 & $86,607 \mathrm{a}^{2}$ & $22,057 \mathrm{a}$ & $26.5 \mathrm{a}$ & $9.2 \mathrm{c}$ & $1,692 \mathrm{~b}$ \\
45 & $78,487 \mathrm{~b}$ & $18,786 \mathrm{~b}$ & $25.3 \mathrm{~b}$ & $10.5 \mathrm{~b}$ & $1,814 \mathrm{a}$ \\
30 & $67,861 \mathrm{c}$ & $14,987 \mathrm{c}$ & $24.5 \mathrm{c}$ & $13.2 \mathrm{a}$ & $1,824 \mathrm{a}$ \\
\hline
\end{tabular}

${ }^{1}$ Includes averages of 19 grasses at three cutting intervals ( 30,45 , and 60 days).

${ }^{2}$ Means followed by the same letter are not significantly different at the 0.05 level of probability.

The highest CP yield at the 30-day interval was produced by Digitaria decumbens (PRPI 6439) with $2,179 \mathrm{~kg} / \mathrm{ha} /$ year. Stargrass presented the highest CP yield at the 45-day interval with $2,141 \mathrm{~kg} / \mathrm{ha} /$ year. Congo (PRPI 5366) had the lowest CP yield with $1,460 \mathrm{~kg} / \mathrm{ha} /$ year. Stargrass had the highest CP yield with $2,030 \mathrm{~kg} / \mathrm{ha} /$ year at the 60 -day interval. The lowest CP yield at the 60-day interval was observed on D. pentzii $\times$ D. pentzii (PRPI 9620) with $1,158 \mathrm{~kg} /$ ha/year.

The average CP yield of the 19 grasses at the 30-, 45-, and 60-day interval were $1,824,1,814$, and $1,692 \mathrm{~kg} /$ ha/year, respectively (table 5 ). No significant differences were observed between the average CP yield of grasses at the 30- and 45-day intervals, but these in turn were significantly higher than those at the 60-day interval.

\section{DRY MATTER AND MINERAL CONTENT}

The DM of the 19 grasses at the 30-, 45-, and 60-day harvest intervals are shown in tables 2 to 5 . At the 30-day harvest interval stargrass (PRPI 2341) had the highest DM content, $29.5 \%$, which was significantly different from that of the other grasses. Digitaria setivalva (PRPI 6402) had the lowest DM at the 30-day interval with $20.2 \%$. Stargrass had also the highest DM at the 45 -day interval with $32.5 \%$, significantly different in this respect from the other grasses. The lowest DM at the 45-day interval was observed on D. setivalua (PRPI 6402) with $21.1 \%$. As in the previous cases, stargrass had the highest DM content at the 60-day 
interval with $33.1 \%$ being significantly higher than that of the other 18 grasses at the $5 \%$ level. D. setivalua (PRPI 6402) had the lowest DM content at the 60-day interval with $22.8 \%$.

On the average the DM content of the grasses increased with length of the harvest interval. At the 30-, 45-, and 60-day intervals the 19 grasses had an average of $24.5,25.3$, and $26.5 \%$, respectively. The DM of the 19 grasses at the 60-day interval were significantly higher than those at the 45- and 30-day intervals. Likewise, the DM of the 19 grasses at the 45-day interval, on the average, were significantly higher than those obtained with a 30-day harvest interval.

The average $\mathrm{P}, \mathrm{K}, \mathrm{Ca}$, and $\mathrm{Mg}$ contents of the 19 grasses varied as indicated below. A marked decrease in the $\mathrm{K}$ content of the forage and a less marked decrease in the $\mathrm{P}, \mathrm{Ca}$, and $\mathrm{Mg}$ contents were observed on these forages as the length of harvest interval increased. The average $P$ content of the 19 grasses at the 30-, 45-, and 60-day harvest interval was $0.38,0.32$, and $0.30 \%$, respectively. The harvest interval apparently had little effect on the $\mathrm{P}$ content of the forage. The average $\mathrm{K}$ content of the 19 forages at the 30-, 45-, and 60-day interval was 1.81, 1.47, and 1.42\%, respectively. A sharp decrease was observed on the $K$ content of the forages from the 30 - to the 45-day interval as was observed in the case of the $\mathrm{P}$ content. The average Ca content of the 19 grasses was $0.65,0.64$, and $0.62 \%$ for the $30-, 45-$, and 60-day intervals, respectively. The average $\mathrm{Mg}$ content of the 19 grasses at the 30-, 45-, and 60-day intervals was $0.21,0.17$, and $0.15 \%$, respectively. Apparently the harvest interval had little effect on the Ca content of the forage.

\section{EFFECT OF SEASON OF THE YEAR}

Vicente Chandler, et al. (18) have shown that, in the humid mountain region of Puerto Rico, short days and cooler weather are the most important factors responsible for the relatively low yields during December to April. In the present study the lowest DFY in the 19 grasses corresponded to the period of December to April during the first year of experimentation when rainfall was the lowest. On the other hand, this same period during the second year had more rainfall and yields were higher (fig. 4). Also the CP content of the 19 forages was consistently lower during seasons of high rainfall (fig. 5 ).

The influence of temperature on the seasonal yields of dry forage produced by the 19 forage grasses cut every 30,45 , and 60 days is shown in figure 6. High temperatures were associated with higher yields and vice versa. The influence of temperature on CP content of the 19 forage grasses when cut every 30,45 , and 60 days is shown in figure 7 . The percent CP content of the forages was consistently higher during the winter months and lower during the rest of the year. 


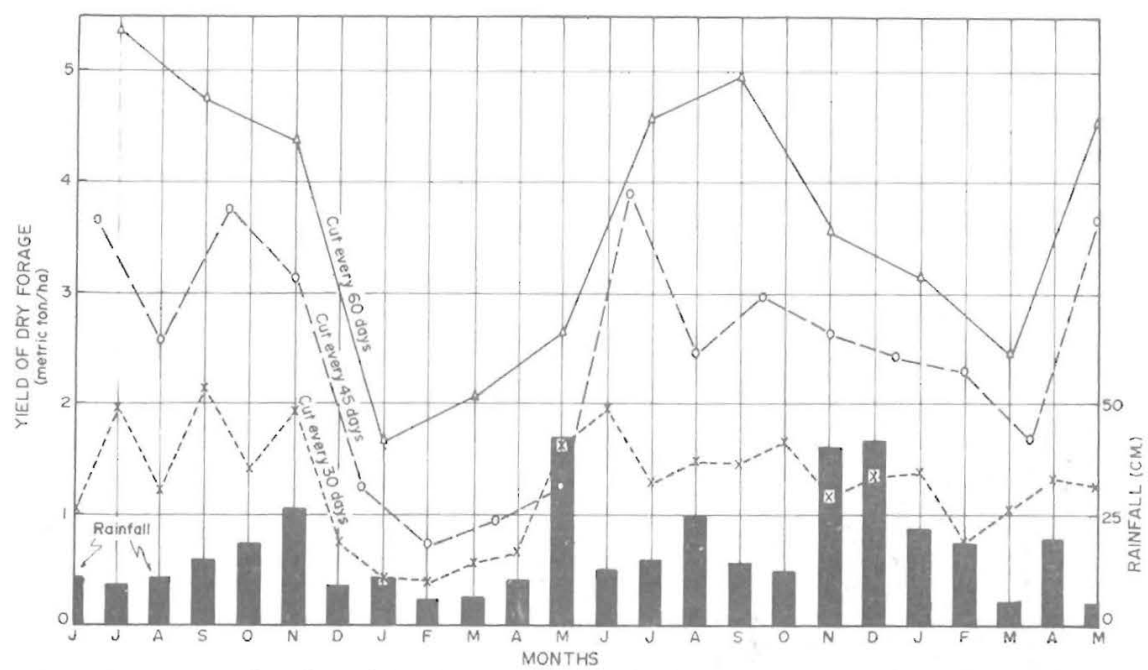

Fig. 4.-Seasonal yields of dry forage per acre of 19 grasses cut every 30, 45, and 60 days over a 2-year period at Corozal, P.R.

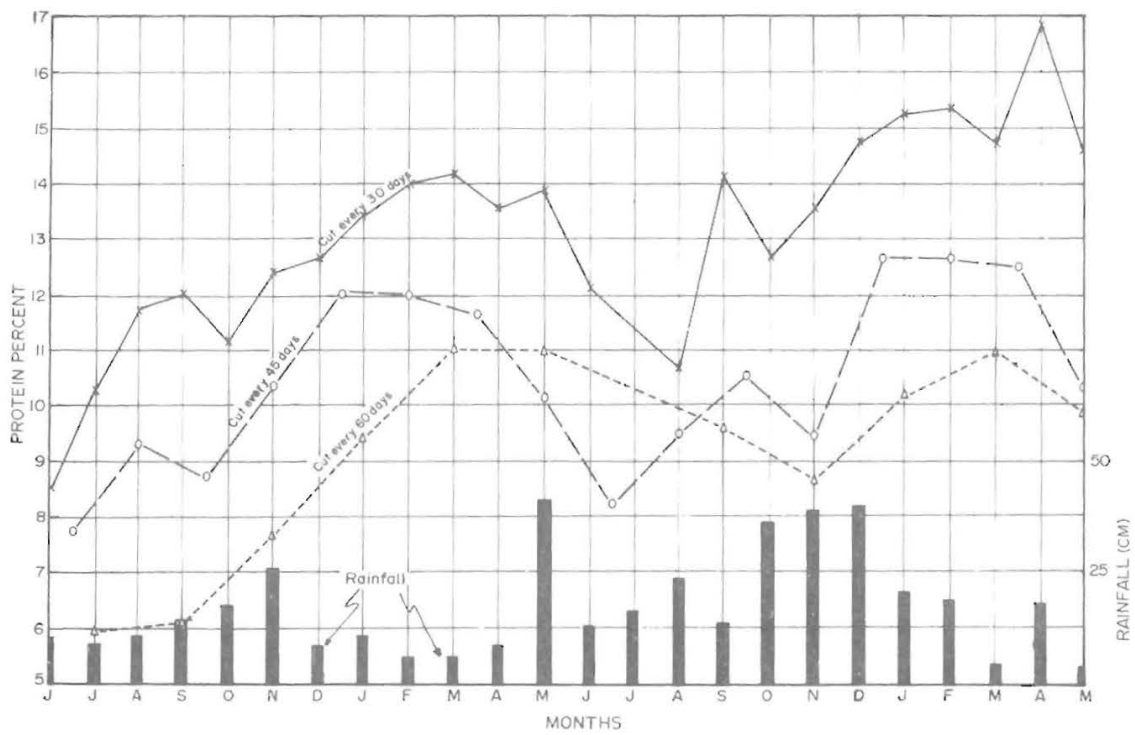

Fig. 5.-Seasonal crude protein content per acre of 19 grasses cut every 30, 45, and 60 days over a 2-year period at Corozal, P.R.

The influence of average temperature, percent CP content, and DFY of the 19 grasses was studied by simple regression analysis. No correlation was obtained between total rainfall, percent CP content, and DFY of the 19 grasses; therefore, these data were excluded from the regression 


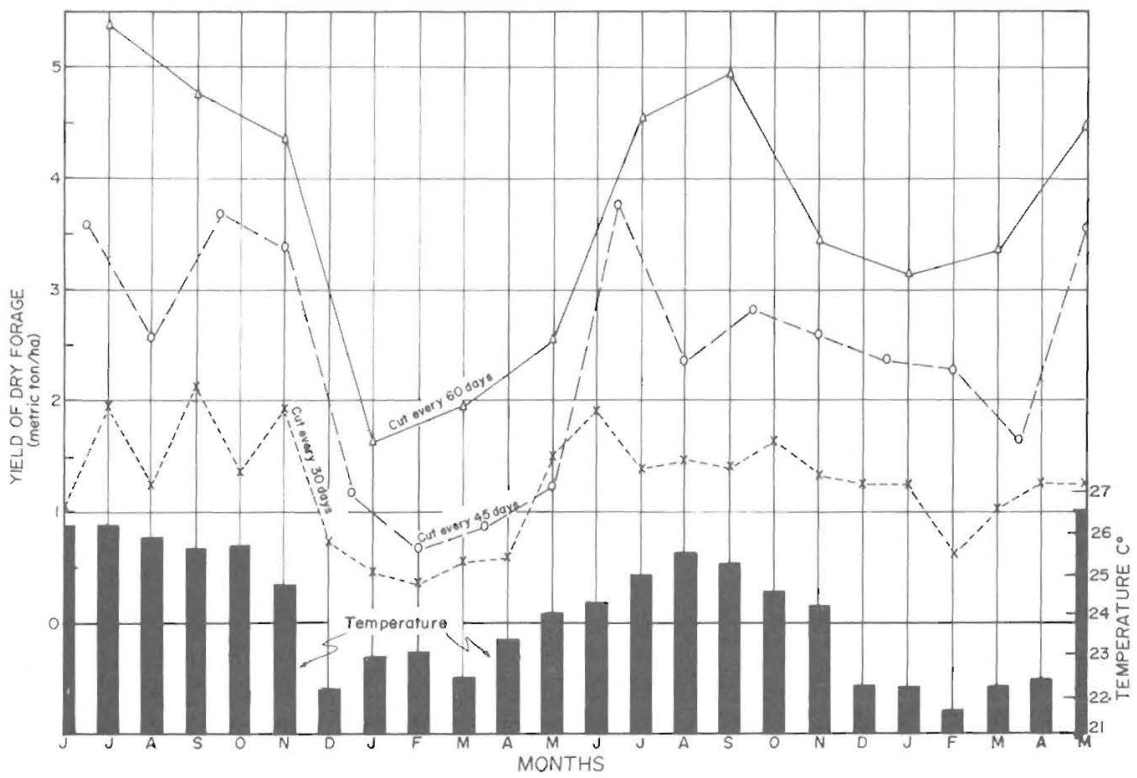

Fig. 6.-Seasonal yields of dry forage per acre of 19 grasses cut every 30,45 , and 60 days, as influenced by temperature, over a 2 -year period at Corozal, P.R.

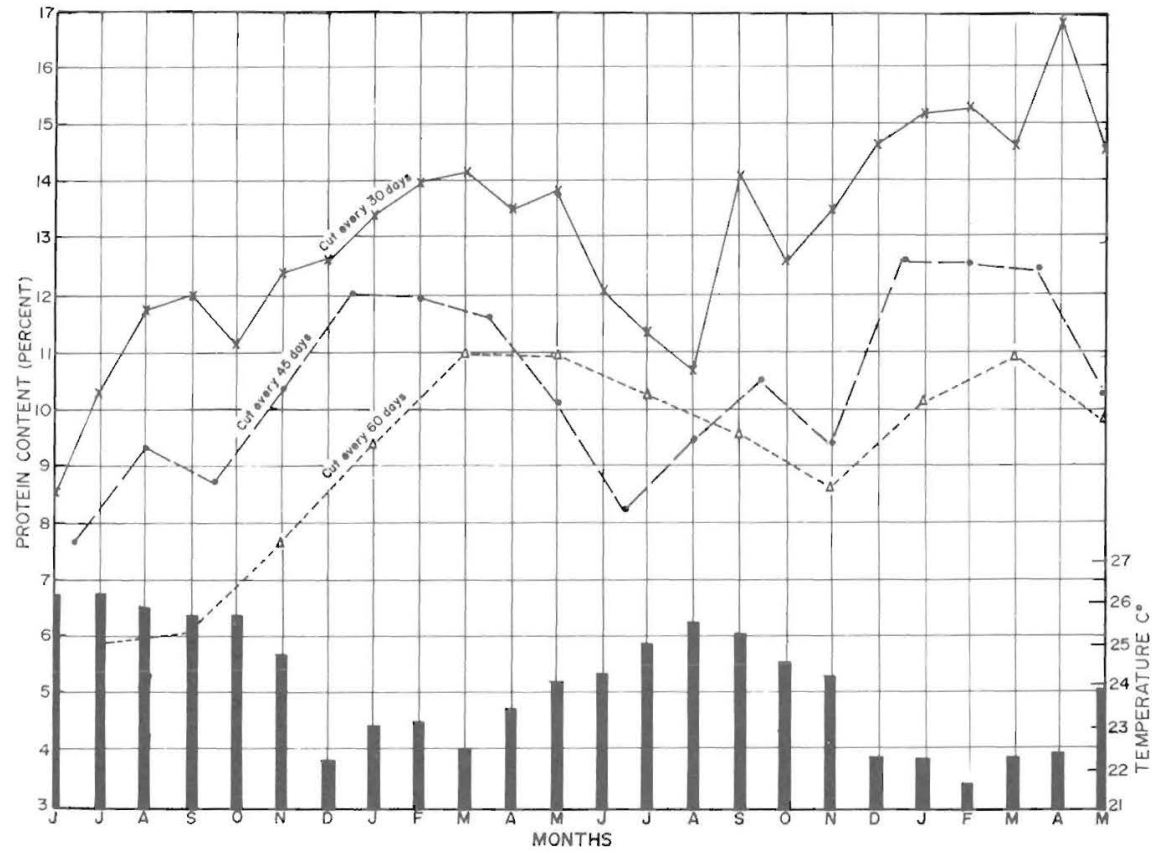

Fig. 7.-Crude protein percentage of 19 grasses cut every 30,45 , and 60 days, as influenced by temperature, over a 2-year period at Corozal, P.R. 
model. The relationship between yield of $\mathrm{DF} /$ ha produced by the 19 grasses cut every 30,45 , and 60 days over a 2 -year period at Corozal and temperature is shown in figure 8. As the temperature increased, the yields of the 19 grasses increased. The $r$ value for yield of DF and

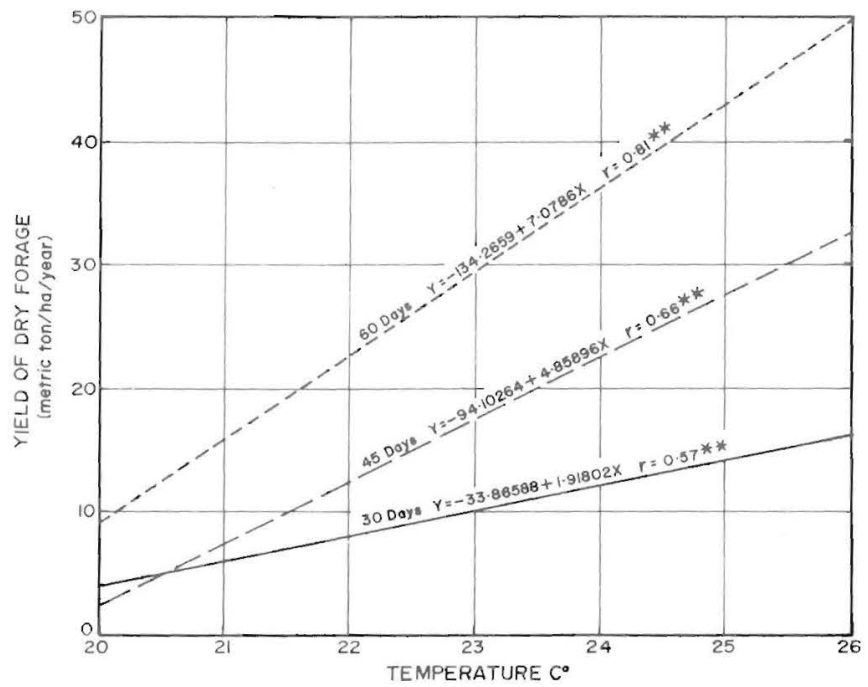

Fig. 8.-Relationship over a 2-year period between yield of dry forage per acre of 19 grasses cut every 30,45 , and 60 days, and temperature, at Corozal, P.R.

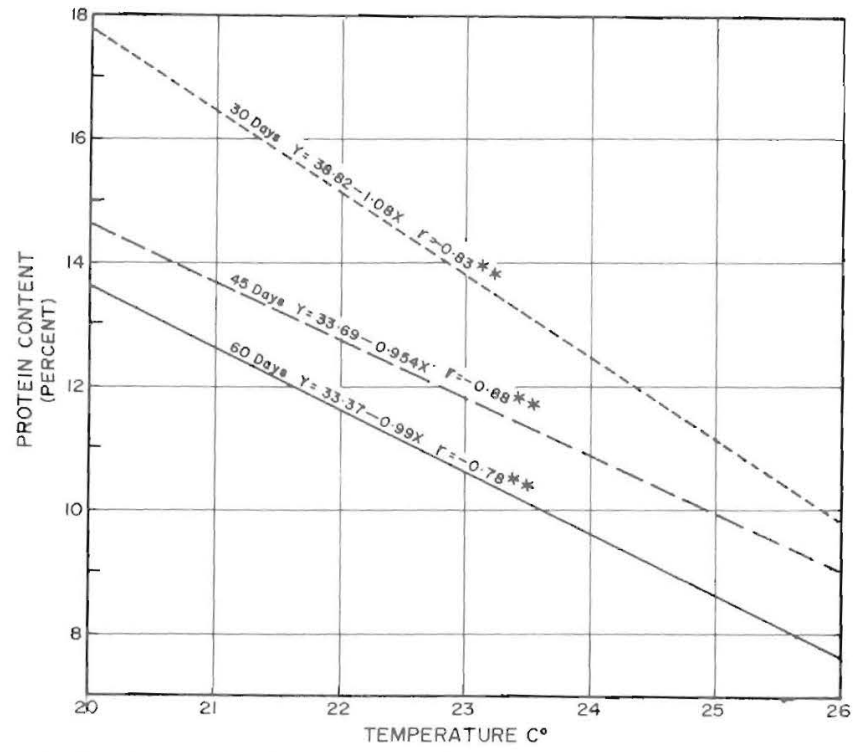

Fig. 9.-Relationship over a 2-year period between crude protein content of 19 grasses cut every 30,45 , and 60 days, and temperature, at Corozal, P.R. 
temperature increased with harvest interval from 30 to 60 days $(0.57$ to 0.81). The relationship between CP content and temperature is shown in figure 9 . The correlation between $\mathrm{CP}$ content and temperature decreased with harvest interval from 30 to 60 days $(-0.83$ to -0.78$)$.

\section{RESUMEN}

Los rendimientos de forraje verde (FV), materia seca (MS) y proterna bruta (PB) se determinaron en 19 yerbas pertenecientes a los géneros Cynodon, Brachiaria y Digitaria durante un período de 2 años.

La mejor productora en términos de FV en el corte a 30 días fue Digitaria setivalva (PRPI 6402), mientras que a 45 y 60 días correspondió a Brachiaria sp. (PRPI 9626).

Estas yerbas produjeron 86,794, 102,116 y 109,213 kg. de FV por hectárea y año, en los cortes a 30, 45 y 60 días, respectivamente. Las producciones medias de FV por hectárea y año de las 19 yerbas aumentaron según se alargó el intervalo de corte.

Las mejores productoras en términos de MS en los cortes a 30, 45 y 60 días fueron Brachiaria sp. (PRPI 9626), Estrella (PRPI 2341) y Brachiaria decumbens (PRPI 5365) con un total de 18,430, 21,758 y 27,238 $\mathrm{kg}$./ha./año, respectivamente. Las producciones medias de MS por año de las 19 yerbas aumentaron según se alargó el intervalo de corte.

Digitaria pentzii $\times$ D. smutsii $($ PRPI 9621), D. pentzii $\times$ D. milanjiana (PRPI 9619), D. pentzii $\times$ D. pentzii (PRPI 9620), mostraron el contenido de PB mas alto en los cortes de 30,45 y 60 días con $14.3,12.0$ y $11.1 \%$, respectivamente. El contenido medio de PB de las 19 yerbas, disminuyó a medida que se alargó el intervalo de corte.

Digitaria decumbens (PRPI 6439) en el corte a 30 días y Estrella en los cortes de 45 y 60 días fueron les mejores productoras en términos de PB total con 2,179, 2,141 y 2,030 kilogramos por hectárea y año, respectivamente.

La yerba Estrella mostró tener el porcentaje más elevado en de MS los intervalos de corte a 30, 45 y 60 días, con $29.5,32.5$ y $33.1 \%$, respectivamente. El contenido medio de MS de las 19 yerbas, aumentó según se alargó el intervalo de corte.

El contenido en fósforo, magnesio y potasio en el forraje también disminuyó a medida que se alargó el intervalo de corte. Por otro lado, tuvo muy poco efecto sobre el contenideo en calcio.

Se obtuvo una correlación positiva significativa entre la producción de MS total de las 19 yerbas y la temperatura media para los cortes a 30, 45 y 60 días. Por otro lado, la correlación entre el contenido en PB y la temperatura media fue negativa, pero significativa. No se observó correlación significativa alguna entre lluvia y producción total de MS o el contenido en PB y lluvia. 


\section{LITERATURE CITED}

1. Boyd, F. T., Schank, S. C., Smith, R. L. Hodges, E. M., West, S. H., Kretschmer, A. E.. Jr., Brolmann, J. B., and Moore, J. E., Transvala Digitgrass, Circ. 5-222, Fla. Agr. Exp. Sta. Univ. Fla., April 1973.

2. Caro-Costas, R., Abruña, F., and Figarella, J., Effect of nitrogen rates, harvest interval and cutting heights on yield and composition of Stargrass in Puerto Rico, J. Agr. Univ, P. R. 56(3): 267-79, 1972.

3. - and Vicente-Chandler, J., Effect of two cutting heights on yields of five tropical grasses. J. Agr. Univ. P. R. 45(1): 46-9, 1961.

4. - - - and Figarella, J., The yield and composition of five grasses growing in the humid mountains of Puerto Rico as affected by nitrogen fertilization, season and harvest procedure, J. Agr. Univ. P. R. 44(3): 107-20, 1960.

5. Harlan, J. R., Cynodon species and their value for grazing and hay, Herb Abstr, 40(3): $233-8,1970$.

6. Hodges, E. M., and Schank, S. C., Registration of Slenderstem Digitgrass, Crop Sci. 12(5): 715, 1972.

7. Nestel, B. L., and Creek, M. J., Pangola grass, Herb. Abstr. 32: 1-7, 1962.

8. Oaks, A. J., Digitaria collection in South Africa, Trop. Agr. 42: 323-31, 1965.

9. Semple, A. T., Grassland improvement (Plant Science Monograph, N. Polunin, Ed.) Leonard Hill, London, pp. 1-400, 1972.

10. Schank, S. C., Hodges, E. M., Killinger, G. B., and McCloud, D. E., Registration of Pangola Digitgrass, Crop Sci. 12(5): 715, 1972.

11. Sotomayor-Ríos, A., Acosta-Matienzo, A., and Velez-Fortuño, J., Evaluation of seven forage grasses at two cutting stages, J. Agr. Univ. P. R. 57(3): 173-85, 1973.

12. - Juliá, F., and Arroyo-Aguilú, J. A., Yield and nutritive evaluation of ten forage grasses as affected by frequency of cutting, J. Agr. Univ. P. R. 58(4): 448-55, 1974.

13. — Rodríguez-García, J., and Silva, S., Yield comparison of four forage grasses at two cutting heights and three harvest intervals, J. Agr. Univ. P. R. 58(1): 26-36, 1974.

14. —- Vélez-Fortuño, J., and Spain, G., Forage yields and plant character correlations in 30 Digitaria selections, J. Agr. Univ. P. R. 55(1): 53-62, 1971.

15. Vicente-Chandler, J., Figarella, J., and Silva, S., Effects of nitrogen fertilization and frequency of cutting on the yield and composition of Pangola grass in Puerto Rico., J. Agr. Univ. P. R., 45(1): 37-45, 1961.

16. - Silva, S., and Figarella, J., The effect of nitrogen fertilization and frequency of cutting on the yield and composition of three tropical grasses, Agron. J. 51: 202-6, 1959.

17. Vicente-Chandler, J., Silver, S., Abruña, F., and Rodriguez, J. A., Effect of two cutting heights, four harvest intervals and five nitrogen rates on yield and composition of Congo grass under humid tropical conditions, J. Agr. Univ. P. R. 56(3): 280-91, 1972.

18. Caro-Costas, R., Pearson, R. W., Abruña, F., Figarella, J., and Silva, S., The intensive management of tropical forages in Puerto Rico, Agr. Exp. Sta., Univ. P. R. Bull. 187, 152 pp. 1964. 